\title{
Quantum Chemical Studies of the Substituent Effect on the Reaction of Carbonyl Oxime with Amine
}

Yunus Kaya*

*Correspondence to: Bursa Tech Univ, Fac Nat Sci Architecture \& Engn, Dept Chem, TR-16190 Bursa, Turkey.

E-mail: yunus.kaya@btu.edu.tr

\section{Supporting Information}

\section{Experimental Section}

Synthesis. The all compounds were prepared by refluxing a mixture of a solution containing respective carbonyl oximes $(5 \mathrm{mmol})$ in $10 \mathrm{~mL}$ of $\mathrm{EtOH}$ and a solution containing amine $(5 \mathrm{mmol})$ in $5 \mathrm{~mL}$ of $\mathrm{EtOH}$. The reaction mixture was stirred for $3 \mathrm{~h}$ under reflux (Scheme 1). The volumes of the solutions were reduced to $10-15 \mathrm{ml}$ under vacuum and then the resulting precipitates were filtered, and dried in air. Ib: [Yield: 81\%] Analysis: Calculated for $\mathrm{C}_{19} \mathrm{H}_{17} \mathrm{NO}_{2}\left(291.3 \mathrm{~g} \mathrm{~mol}^{-1}\right): \mathrm{C}, 78.33 ; \mathrm{H}, 5.88 ; \mathrm{N}$, 4.81. Found: C, 78.45; H, 5.68; N, 4.83\%. ${ }^{1} \mathrm{H}$ NMR (400 MHz, DMSO-d $6.298 \mathrm{~K}$, $\delta / p p m): 8.61(\mathrm{~s}, 1 \mathrm{H}) ; 8.09-7.30(\mathrm{~m}, 12 \mathrm{H}) ; 4.88(\mathrm{~s}, 1 \mathrm{H}) ; 3.12(\mathrm{t}, 1 \mathrm{H}) ; 2.84-2.78(\mathrm{~d}, 2 \mathrm{H})$. ${ }^{13} \mathrm{C}$ NMR (100 MHz, DMSO-d 6 , $\left.298 \mathrm{~K}, \delta / \mathrm{ppm}\right): 171.1 ; 144.6-127.9 ; 70.8 ; 47.3$. IR (Solid $\mathrm{KBr}$ pellet): $v\left(\mathrm{~cm}^{-1}\right)$ 3463br, 3201m, 1620m. Ila: [Yield: 73\%] Analysis: Calculated for $\mathrm{C}_{14} \mathrm{H}_{14} \mathrm{~N}_{2} \mathrm{O}_{2}\left(242.3 \mathrm{~g} \mathrm{~mol}^{-1}\right)$ : C, 69.41; $\mathrm{H}, 5.82 ; \mathrm{N}, 11.56$. Found: $\mathrm{C}$, 69.49; H, 5.61; N, 11.21\%. ${ }^{1} \mathrm{H}$ NMR (400 MHz, DMSO-d, 298 K, $/ \mathrm{ppm}$ ): 11.70 (s, 1H); 7.48 (s, 1H); 8.01-7.30 (m, 7H); 4.58 (s, 1H); 3.63-3.59 (m, 2H); 3.40-3.35 (m, 2H). ${ }^{13} \mathrm{C}$ NMR (100 MHz, DMSO-d 6 , 298 K, ס/ppm): 166.2; 161.0; 152.7-126.0; 61.5; 56.4. IR (Solid KBr pellet): v( $\left.\mathrm{cm}^{-1}\right)$ 3429br, 3229br, 1612s, 1593s, 995s. IIIb: [Yield: 86\%] Analysis: Calculated for $\mathrm{C}_{15} \mathrm{H}_{14} \mathrm{~N}_{2} \mathrm{O}_{4}\left(286.3 \mathrm{~g} \mathrm{~mol}^{-1}\right)$ : C, 62.93; $\mathrm{H}, 4.93 ; \mathrm{N}, 9.79$. Found: C, 62.91; H, 4.79; N, 9.84\%. ${ }^{1} \mathrm{H}$ NMR (400 MHz, DMSO-d 6 , $\left.298 \mathrm{~K}, \delta / \mathrm{ppm}\right)$ : $10.68(\mathrm{~s}, 1 \mathrm{H}) ; 10.49-9.20(\mathrm{~m}, 9 \mathrm{H}) ; 5.68(\mathrm{~s}, 1 \mathrm{H}) ; 3.32(\mathrm{t}, 1 \mathrm{H}) ; 2.24-2.18(\mathrm{~d}, 2 \mathrm{H}) .{ }^{13} \mathrm{C}$ 
NMR (100 MHz, DMSO-d 6 , 298 K, ס/ppm): 167.3; 153.0-125.4; 75.2; 64.1. IR (Solid $\mathrm{KBr}$ pellet): $v\left(\mathrm{~cm}^{-1}\right) 3448 \mathrm{br}, 3174 \mathrm{~m}, 1643 \mathrm{~m}$. IVb: [Yield: $79 \%$ ] Analysis: Calculated for $\mathrm{C}_{9} \mathrm{H}_{10} \mathrm{~N}_{2} \mathrm{O}_{4}\left(210.2 \mathrm{~g} \mathrm{~mol}^{-1}\right): \mathrm{C}, 51.43 ; \mathrm{H}, 4.80 ; \mathrm{N}, 13.33$. Found: $\mathrm{C}, 51.57 ; \mathrm{H}, 4.71 ; \mathrm{N}$, 13.21\%. ${ }^{1} \mathrm{H}$ NMR (400 MHz, DMSO-d 6 , $\left.298 \mathrm{~K}, \delta / \mathrm{ppm}\right): 8.04(\mathrm{~s}, 1 \mathrm{H}) ; 9.28-8.12(\mathrm{~m}$, $4 \mathrm{H}) ; 3.91(\mathrm{~s}, 1 \mathrm{H}) ; 3.39-3.70(\mathrm{~m}, 2 \mathrm{H}) ; 2.61-2.51(\mathrm{~m}, 2 \mathrm{H}) .{ }^{13} \mathrm{C}$ NMR $(100 \mathrm{MHz}$, DMSO$\mathrm{d}_{6}, 298 \mathrm{~K}, \delta / \mathrm{ppm}$ ): 189.3; 149.8-123.7; 63.0; 44.2. IR (Solid $\mathrm{KBr}$ pellet): $v\left(\mathrm{~cm}^{-1}\right)$ $3471 \mathrm{br}, 3193 \mathrm{~m}, 1639 \mathrm{~m}$.

\section{Result and Discussion}

Synthesis. The synthesis of all molecules are given in Scheme 1. Generally, all of the molecules were synthesized by reaction of carbonyl oxime (isonitrosoacetylnaphtaline, inanH and nitro-isonitrosoacetophenone, ninapH) with amine (1-phenylethanol amine, pea and ethanol amine, ea) afforded moderate to good yields (73-86\%) of imine oxime or amido alcohol. In this study, the effect on product formation, which is imine oxime (I-IVa) or amido alcohol (I-IVb) was investigated different substituents. In this context, two different carbonyl oximes (whose substituents are naphthyl and nitrophenyl) and two different amines (whose substituents are phenyl and hydrogen) have been selected. The synthesized compounds were characterized by elemental analyses, IR, ${ }^{1} \mathrm{H}$ and ${ }^{13} \mathrm{C} N M R$ spectral data. All were compared with their previous analogues. According to elemental analysis, the results measured with the proposed structures for the four products (Ib, Ila, IIlb and IVb) are compatible. These results are showed that as a result of the reaction between inanH and ethanol amine (ea), imine oxime (Ila) is obtained, while the amido alcohols (Ib, IIlb and IVb) are synthesized the other reactions between carbonyl oxime and amine.

IR Spectra. The IR spectra of all molecules were measured in the frequency range $4000-400 \mathrm{~cm}^{-1}$ as $\mathrm{KBr}$ pellet, while the harmonic vibrational frequencies were calculated by using DFT method at $6-311 \mathrm{G}(\mathrm{d}, \mathrm{p})$ basis set. The obtained and the calculated values scaled as explained in the theoretical methods of some important frequencies are given in Table S1. The experimentally and theoretically IR spectra of all molecules are demonstrated in Figs. S1 and S2. In general, the absorption frequencies obtained from experiment and theory is in good agreement. In the IR spectra of $\mathbf{I b}$, Ila, IIIb and IVb, the $\mathrm{OH}$ stretching vibrations of the hydroxyethyl group 
were calculated at ca. $3668 \mathrm{~cm}^{-1}$, while observed at 3463, 3429, 3448 and $3471 \mathrm{~cm}^{-1}$, respectively. In addition, the $\mathrm{OH}$ stretching vibration of oxime group in lla molecule was measured at $3229 \mathrm{~cm}^{-1}$ (calcd. $3642 \mathrm{~cm}^{-1}$ ). The deviation between the experimental and calculated values seems to be significant for the hydroxyl groups' frequencies. There are two reasons for this difference: (i) Due to the nature of this vibration mode, its frequency is very sensitive to the crystalline state, in which the hydrogen bonding interactions involving this group are present as discussed above, (ii) In the high wave number region of the spectra, the anharmonicity can explain substantial differences between the experimental and calculated values and thus exhibits much larger deviation from the calculated values. In such reactions, the most important evidence of performing the reactions are the carbonyl stretchings of carbonyl oxime and amine oxime. The carbonyl stretchings are observed at 1624 and $1639 \mathrm{~cm}^{-1}$, respectively for inanH and ninapH. The amine stretchings are measured at $3408 / 3303$ and $3351 / 3266 \mathrm{~cm}^{-1}$, respectively for pea and ea. In the final product, these vibrational stretchings are not observed. Instead of these band, $v(\mathrm{CO}) / v(\mathrm{NH})$ of amide groups were observed at 3201/1620, 3174/1643 and 3193/1639 $\mathrm{cm}^{-1}$ for Ib, IIIb and IVb, respectively, while calculated at 3497/1653, 3491/1677 and 3494/1674 $\mathrm{cm}^{-1}$ respectively. The imine stretching was measured at $1612 \mathrm{~cm}^{-1}$ (calcd. $1648 \mathrm{~cm}^{-}$ ${ }^{1}$ ) in Ila. These calculated values are higher than the observed values, due to intermolecular hydrogen bonding.

Finally, the most important IR band is the stretching vibration of NO group. This group indicates that the final product is imine oxime or amido alcohol. The stretching vibrations of $\mathrm{NO}$ group of the starting materials, inanH and ninapH are appeared at 1011 and $1007 \mathrm{~cm}^{-1}$, respectively. This band is disappeared in $\mathbf{~ l b}$, IIIb and IVb, while observed as strongly at $995 \mathrm{~cm}^{-1}$ in Ila. These results indicate that as a result of the reaction between inan $\mathrm{H}$ and ea, imine oxime (Ila) is observed at 995 $\mathrm{cm}^{-1}$ while the amido alcohols (Ib, IIIb and $\mathbf{I V b}$ ) are synthesized in the other reactions, which are between inanH and pea, ninapH and pea, ninapH and ea. The NO stretching vibration of Ila is calculated at $999 \mathrm{~cm}^{-1}$. 


\section{Table S1}

Experimental FT-IR and DFT-B3LYP/6-311G(d,p) calculated spectra for Ib, Ila, IIlb and $\mathbf{I V b}$ together with their assignment ${ }^{\mathrm{a}}$ (wavenumber in $\mathrm{cm}^{-1}$ ).

\begin{tabular}{|c|c|c|c|c|c|c|c|c|}
\hline & inanH & ninapH & pea & ea & Ib & Ila & IIIlb & IVb \\
\hline$v(\mathrm{OH})_{a \operatorname{mine}}$ & - & T & $3478 \mathrm{br}$ & $3642 m$ & $\begin{array}{c}3436 \mathrm{br} \\
(3668,100 \%)\end{array}$ & $\begin{array}{c}3429 \mathrm{br} \\
(3666,100 \%)\end{array}$ & $\begin{array}{c}3448 \mathrm{br} \\
(3666,100 \%)\end{array}$ & $\begin{array}{c}3471 \mathrm{br} \\
(3669,100 \%)\end{array}$ \\
\hline$v(\mathrm{OH})_{\text {oxime }}$ & $3232 b r$ & $3194 b r$ & - & - & - & $\begin{array}{c}3229 \mathrm{br} \\
(3642,100 \%)\end{array}$ & - & - \\
\hline$v\left(\mathrm{NH}_{2}\right)_{\text {amine }}$ & - & - & $\begin{array}{l}3408 s \\
3303 s\end{array}$ & $\begin{array}{l}3351 \mathrm{~s} \\
3266 \mathrm{~s}\end{array}$ & - & - & - & - \\
\hline$v(\mathrm{NH})_{\text {amide }}$ & - & - & - & - & $\begin{array}{c}3201 \mathrm{~m} \\
(3497,100 \%)\end{array}$ & - & $\begin{array}{c}3174 \mathrm{~m} \\
(3491,100 \%)\end{array}$ & $\begin{array}{c}3193 \mathrm{~m} \\
(3494,100 \%)\end{array}$ \\
\hline$v(\mathrm{CO})$ & $1624 s$ & $1639 \mathrm{~s}$ & - & - & $\begin{array}{c}1620 m \\
(1653,37 \%)\end{array}$ & - & $\begin{array}{c}1643 m \\
(1677,42 \%)\end{array}$ & $\begin{array}{c}1639 m \\
(1674,39 \%)\end{array}$ \\
\hline$v(\mathrm{CN})_{\text {imine }}$ & - & - & - & - & 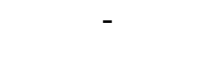 & $\begin{array}{c}1612 \mathrm{~s} \\
(1648,46 \%)\end{array}$ & - & 5. \\
\hline$v(\mathrm{CN})_{\text {oxime }}$ & $1608 \mathrm{~s}$ & $1597 \mathrm{~s}$ & - & - & - & $\begin{array}{c}1593 s \\
(1635,39 \%)\end{array}$ & - & - \\
\hline$v(\mathrm{NO})_{\text {oxime }}$ & $1011 \mathrm{~s}$ & $1007 \mathrm{~s}$ & - & - & - & $\begin{array}{c}995 \mathrm{~s} \\
(999,28 \%)\end{array}$ & - & - \\
\hline
\end{tabular}

${ }^{\mathrm{a}} \mathrm{br}=$ broad, $\mathrm{s}=$ strong, $\mathrm{m}=$ medium; $v=$ stretching.

\section{NMR Spectra}

Experimental ${ }^{1} \mathrm{H}$ and ${ }^{13} \mathrm{C}$ NMR spectra of $\mathbf{I b}$, Ila, IIlb and IVb were measured in DMSO- $d_{6}$ solvent which are showed in Fig. S3. The NMR shifts obtained by the DFT method at the GIAO/B3LYP/6-311G(d,p) level for the compounds with TMS as a reference are illustrated in Fig. S4. The chemical shifts are given in Table S2. The most important chemical shifts are the deuterium exchangeable protons of the hydroxyimino $(-\mathrm{C}=\mathrm{N}-\mathrm{OH})$ and the amino $\left(-\mathrm{NH}_{2}\right)$ groups for these reactions. The deuterium exchangeable protons of the hydroxyimino $(-\mathrm{C}=\mathrm{N}-\mathrm{OH})$ group show a characteristic chemical shift at 11.8 and 12.0 ppm as a singlet in inanH and ninapH, respectively. On the other hand, the deuterium exchangeable protons of the amino ($\mathrm{NH}_{2}$ ) group are observed at $2.8 \mathrm{ppm}$ in both amine, pea and ea. The amino protons are not observed the ${ }^{1} \mathrm{H}$ NMR spectra of the final products, Ib, Ila, IIlb and IVb. These results show that all reactions are worked well. In addition, the proton of the hydroxyimino $(-\mathrm{C}=\mathrm{N}-\mathrm{OH})$ group was observed at $11.7 \mathrm{ppm}$ (calcd. $6.2 \mathrm{ppm})$ in Ila, while this proton was disappeared in $\mathbf{I b}$, IIIb and $\mathbf{I V b}$. These results indicate that as a result of the reaction between inanH and ea, imine oxime (IIa) is obtained, while the amido alcohols (Ib, IIllb and $\mathbf{I V b}$ ) are synthesized in the other reactions, which are between inanH and pea, ninapH and pea, ninapH and ea. In the ${ }^{1} \mathrm{H}$ NMR spectra of 
$\mathbf{I b}$, IIIb and IVb, instead of the protons of the amino group, the characteristic protons of the amide $(-\mathrm{NH})$ group show a characteristic chemical shift at 8.6, 10.7 and 8.0 ppm and they are calculated as 5.0, 5.1 and $5.4 \mathrm{ppm}$, respectively. The singlet $(\mathrm{C} \underline{\mathrm{H}}=\mathrm{N}-\mathrm{OH})$ centered at approximately $7.5 \mathrm{ppm}$ in ${ }^{1} \mathrm{H}$ NMR spectra of lla is assigned to aldehyde proton of the oxime group and this is calculated $8.3 \mathrm{ppm}$. The multiple peaks between 10.5 and $7.3 \mathrm{ppm}$ represent the aromatic protons of phenyl/naphthyl groups and they were calculated at 9.2-6.6 ppm in all compounds. In some cases, especially molecules which has a lot of conformer like imine oxime, the NMR spectrum is not well correlated with the calculated spectrum, since calculations are referred to the static molecule. Therefore, the experimental and calculated spectra are more highly correlated in ${ }^{13} \mathrm{C}$ NMR. The signals at 188.0 and $187.5 \mathrm{ppm}$ belongs to the carbonyl $C$ carbon atom, while the signals at 153.4 and $151.1 \mathrm{ppm}$ are assigned to the $\mathrm{C}$ atom of $\mathrm{C}=\mathrm{N}-\mathrm{O}$ group of the inanH and ninapH, respectively. The signal of the carbonyl $\mathrm{C}$ carbon atom of inan $\mathrm{H}$ molecule was disappeared in the imine oxime (Ila), instead of this signal, a new signal at $166.2 \mathrm{ppm}$, which belongs to carbon atom of imine group was appeared, and calculated at $170.4 \mathrm{ppm}$. The $\mathrm{C}$ atom signal of $\mathrm{C}=\mathrm{N}-\mathrm{O}$ group, observed in inanH and ninapH was not seen in the ${ }^{13} \mathrm{C} N M R$ spectra of $\mathbf{I b}$, IIllb and IVb molecules. These results suggested that the amido alcohols (Ib, Illb and IVb) were obtained by the reaction of the corresponding compounds. The chemical shifts of carbonyl $\mathbf{C}$ atoms of $\mathbf{I b}$, Illb and IVb molecules were observed at 171.1, 167.3 and $189.3 \mathrm{ppm}$, respectively, while the carbonyl C atoms were calculated at $170.7,164.6$ and $176.6 \mathrm{ppm}$. The computed ${ }^{13} \mathrm{C}$ chemical shifts of all molecules observed in the range of 153.0-123.7 ppm are characteristic of a nearly $\mathrm{sp}^{2}$-hybridized carbon atom (compare with the calculated values between 155.3-126.5 ppm). 


\section{Table S2}

Experimental and calculated ${ }^{1} \mathrm{H}$ and ${ }^{13} \mathrm{C}$ NMR chemical shifts of $\mathbf{l b}$, Ila, Illb and IVb. (ppm).

\begin{tabular}{|c|c|c|c|c|c|c|c|c|}
\hline & inanH & ninapH & pea & ea & Ib & Ila & IIIlb & IVb \\
\hline $\begin{array}{l}{ }^{1} H N M R \\
\text { O- } \underline{H}_{\text {oxime }}\end{array}$ & 11.8 & 12.0 & - & - & - & $\begin{array}{l}11.7 \\
(6.2)\end{array}$ & - & - \\
\hline $\mathrm{O}-\underline{H}_{\text {amine }}$ & - & - & 2.8 & 2.8 & $\begin{array}{c}4.9 \\
(1.1)\end{array}$ & $\begin{array}{c}4.6 \\
(0.9)\end{array}$ & $\begin{array}{l}5.7 \\
(1.1)\end{array}$ & $\begin{array}{c}3.9 \\
(0.6)\end{array}$ \\
\hline $\mathrm{N}-\underline{\mathrm{H}}_{2 \text { amine }}$ & - & - & 2.7 & 2.8 & - & - & 1 & - \\
\hline $\mathrm{N}-\underline{-}_{\text {amide }}$ & - & - & - & - & $\begin{array}{c}8.6 \\
(5.0)\end{array}$ & - & $\begin{array}{l}10.7 \\
(5.1)\end{array}$ & $\begin{array}{l}8.0 \\
(5.4)\end{array}$ \\
\hline $\mathrm{C}-\mathrm{H}_{\text {aldehitic }}$ & 8.2 & 8.0 & - & - & - & $\begin{array}{c}7.5 \\
(8.3)\end{array}$ & - & - \\
\hline $\mathrm{C}-\mathrm{H}_{\text {aromatic }}$ & $7.6-7.2$ & 7.8-7.4 & 7.3-7.2 & - & $\begin{array}{c}8.1-7.3 \\
(9.2-7.4)\end{array}$ & $\begin{array}{c}8.0-7.3 \\
(8.2-6.6)\end{array}$ & $\begin{array}{l}10.5-9.2 \\
(8.4-7.2)\end{array}$ & $\begin{array}{c}9.3-8.1 \\
(8.4-7.3)\end{array}$ \\
\hline $\mathrm{C}-\mathrm{H}_{\text {aliphatic }}$ & - & - & $4.6-2.8$ & $3.6-2.8$ & $\begin{array}{c}3.1-2.8 \\
(4.8-2.5)\end{array}$ & $\begin{array}{c}3.6-3.4 \\
(3.9-3.4)\end{array}$ & $\begin{array}{c}3.3-2.2 \\
(4.6-2.5)\end{array}$ & $\begin{array}{c}3.4-2.5 \\
(3.9-2.8)\end{array}$ \\
\hline $\begin{array}{l}{ }^{13} C N M R \\
\underline{\mathrm{C}}=\mathrm{O}\end{array}$ & 188.0 & 187.5 & - & - & $\begin{array}{c}171.1 \\
(170.7)\end{array}$ & - & $\begin{array}{c}167.3 \\
(164.6)\end{array}$ & $\begin{array}{c}189.3 \\
(176.6)\end{array}$ \\
\hline$\underline{\mathrm{C}}=\mathrm{N}_{\text {imine }}$ & - & - & - & - & - & $\begin{array}{c}166.2 \\
(170.4)\end{array}$ & - & - \\
\hline$\underline{\mathrm{C}}=\mathrm{N}_{\text {oxime }}$ & 153.4 & 151.1 & - & - & - & $\begin{array}{c}161.0 \\
(159.7)\end{array}$ & - & - \\
\hline$\underline{\mathrm{C}}$-aromatic & $144.4-126.9$ & $152.2-124.6$ & $142.9-125.9$ & - & $\begin{array}{c}144.6-127.9 \\
(148.4-126.7)\end{array}$ & $\begin{array}{c}152.7-126.0 \\
(146.2-127.8)\end{array}$ & $\begin{array}{c}153.0-125.4 \\
(147.3-126.6)\end{array}$ & $\begin{array}{c}149.8-123.7 \\
(155.3-126.5)\end{array}$ \\
\hline$\underline{\mathrm{C}}$-aliphatic & - & - & $74.2,49.2$ & $63.2,44.0$ & $\begin{array}{c}70.8,47.3 \\
(77.3,52.0) \\
\end{array}$ & $\begin{array}{c}61.5,56.4 \\
(75.2,74.0)\end{array}$ & $\begin{array}{c}75.2,64.1 \\
(77.8,50.7) \\
\end{array}$ & $\begin{array}{c}63.0,44.2 \\
(64.5,45.1)\end{array}$ \\
\hline
\end{tabular}


Table S3

Selected bond lengths $(\AA)$ and angles $\left({ }^{\circ}\right)$ for Ib, Ila, IIllb and IVb

\begin{tabular}{lcccc}
\hline & lb & Ila & IIlb & IVb \\
\hline Bond lengths $(\AA)$ & & & & \\
$\mathrm{C}=\mathrm{O}$ & 1.224 & & 1.221 & 1.221 \\
$\mathrm{~N}-\mathrm{H}$ & 1.007 & & 1.007 & 1.006 \\
$\mathrm{C}-\mathrm{O}$ & 1.427 & 1.412 & 1.425 & 1.420 \\
$\mathrm{O}-\mathrm{H}$ & 0.963 & 0.964 & 0.963 & 0.962 \\
$\mathrm{C}=\mathrm{N}_{\text {imine }}$ & & 1.279 & & \\
$\mathrm{C}=\mathrm{N}_{\text {oxime }}$ & & 1.277 & & \\
$\mathrm{~N}-\mathrm{O}$ & & 1.390 & & \\
$\mathrm{O}-\mathrm{H}_{\text {oxime }}$ & & 0.963 & & \\
$\mathrm{Bond}$ angles $\left({ }^{\circ}\right)$ & & & & \\
$\mathrm{O}-\mathrm{C}-\mathrm{N}$ & & & 122.9 & 122.6 \\
$\mathrm{C}-\mathrm{N}-\mathrm{C}$ & 121.7 & & 122.2 & 121.4 \\
$\mathrm{C}-\mathrm{O}-\mathrm{H}$ & 121.8 & & 108.1 & 108.0 \\
$\mathrm{C}-\mathrm{N}-\mathrm{C}$ & 107.9 & 107.8 & & \\
$\mathrm{C}-\mathrm{N}-\mathrm{O}$ & & 121.2 & & \\
$\mathrm{~N}-\mathrm{O}-\mathrm{H}$ & & 111.4 & & \\
\hline
\end{tabular}


Figure S1. Experimental IR spectra

lb

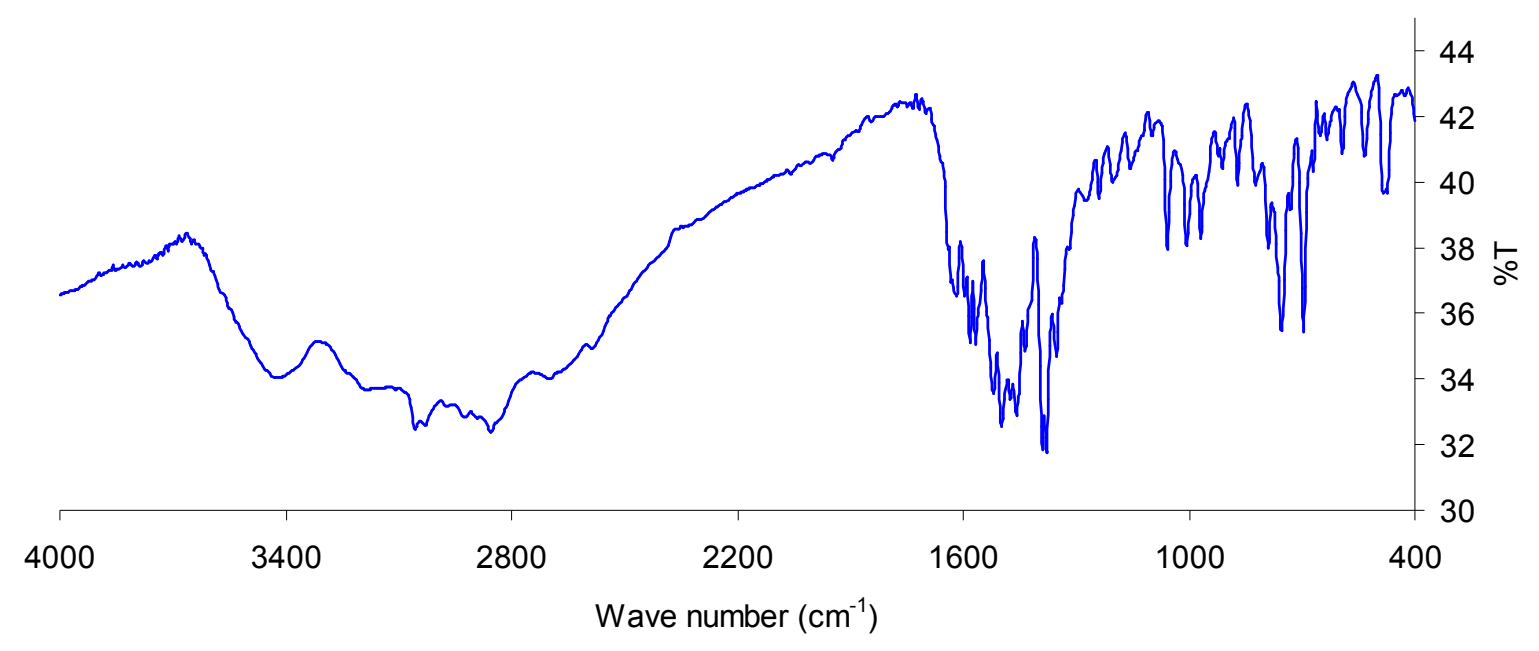

Ila

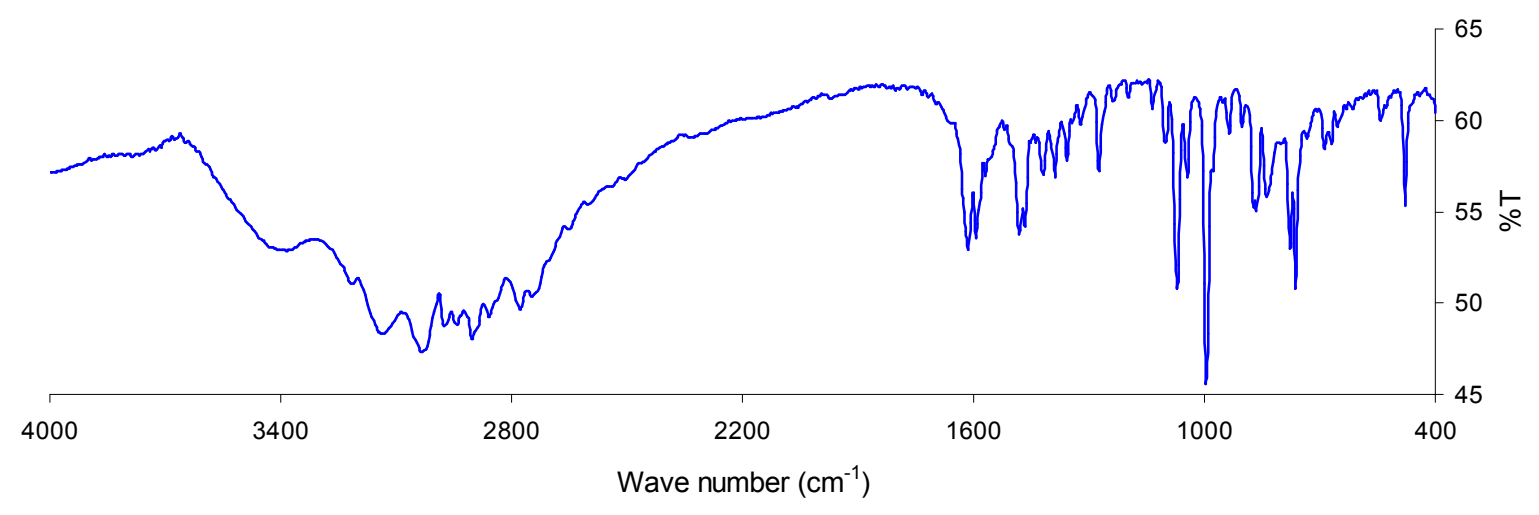




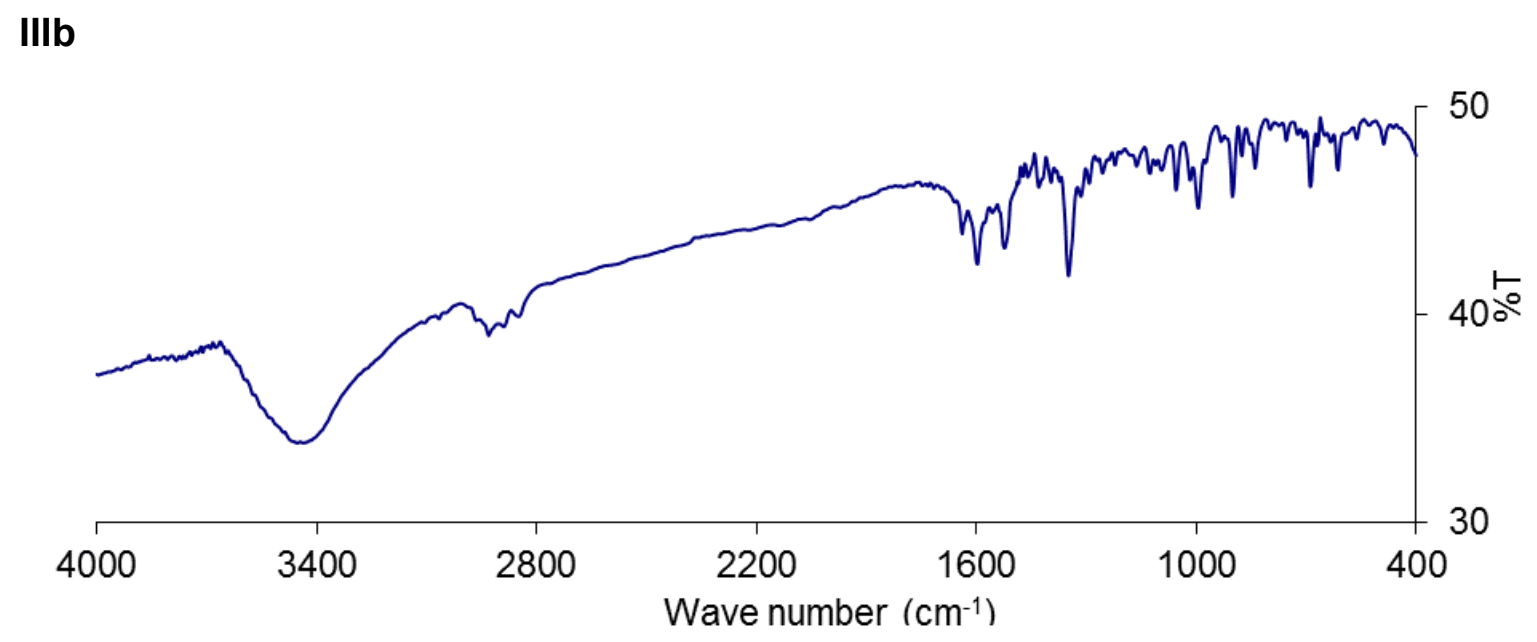

IVb

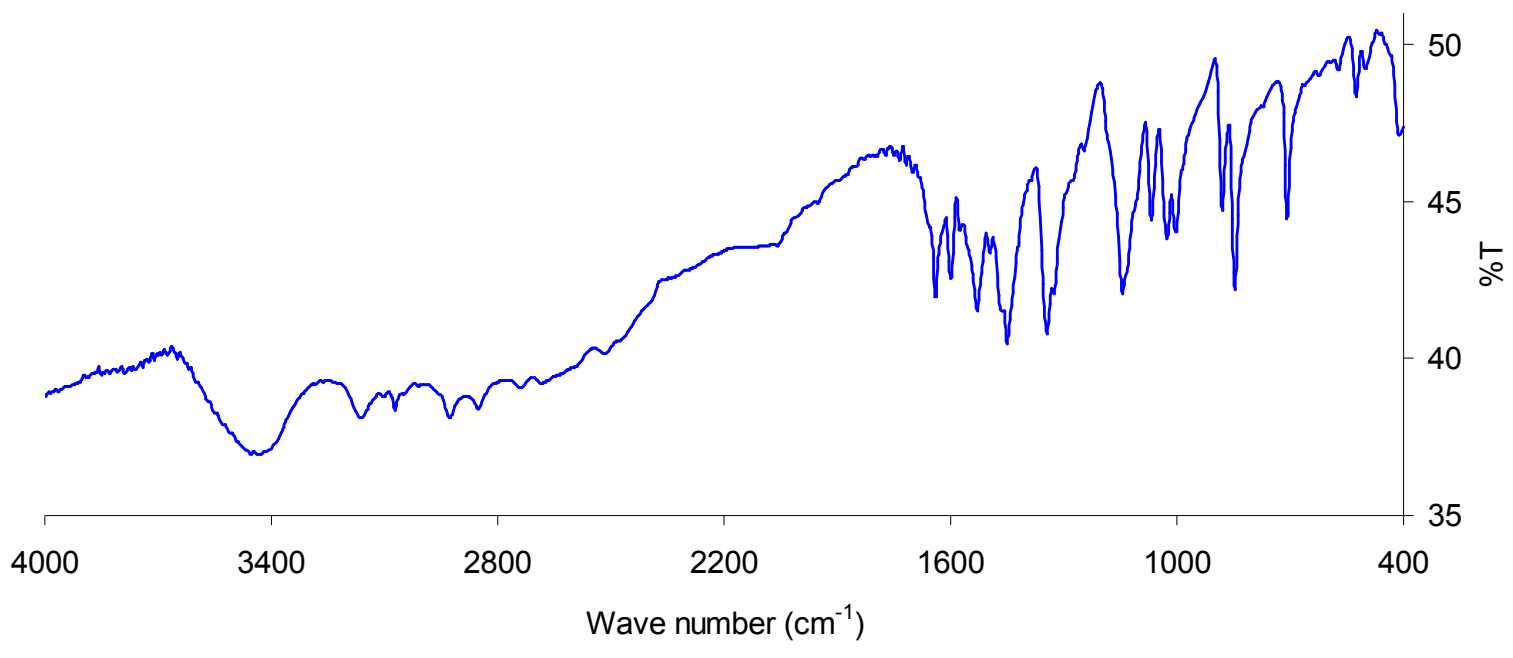


Figure S2. Theoretical IR spectra (Unscaled)

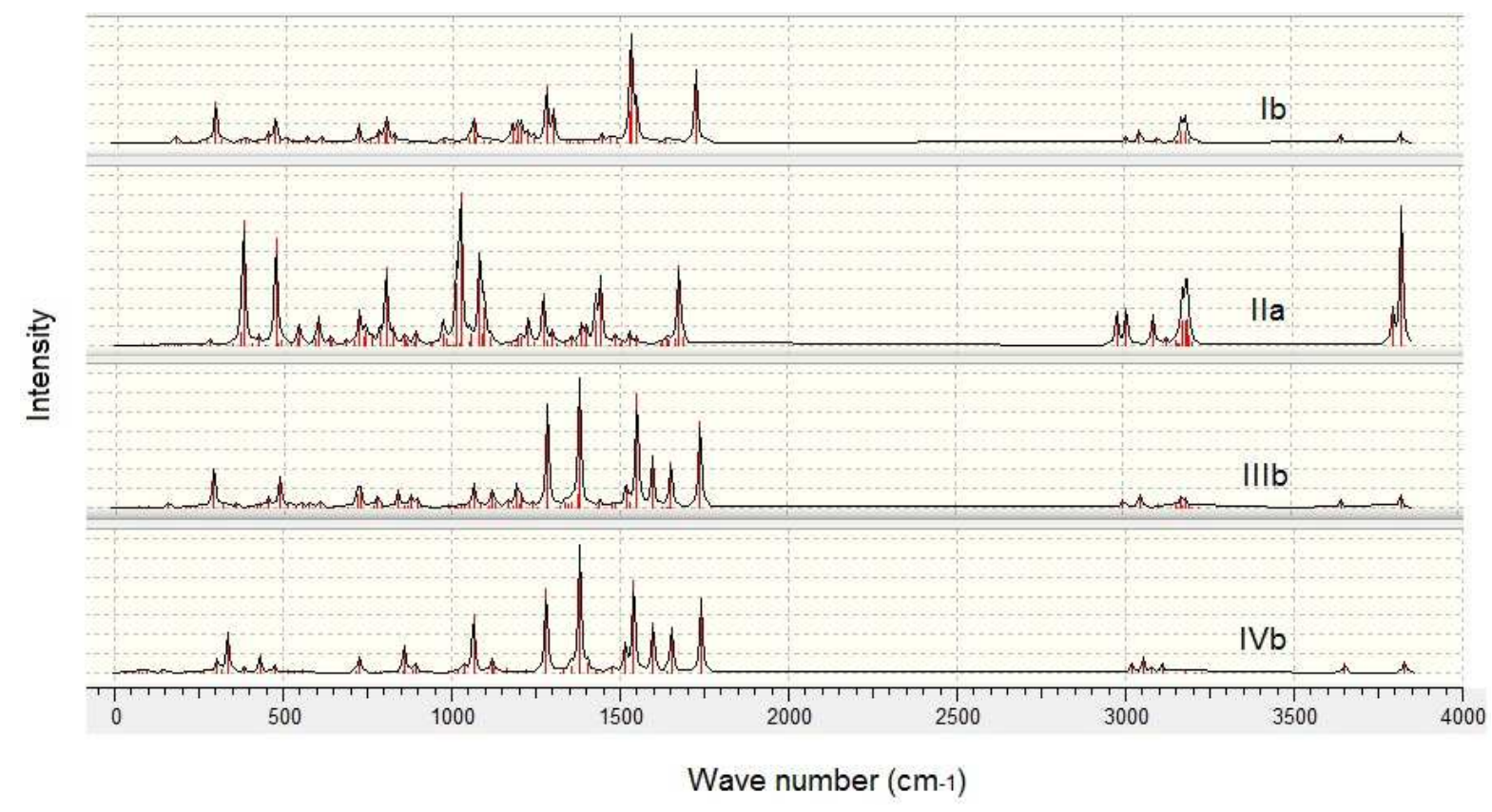


Figure S3. Experimental NMR spectra

lb

${ }^{1} \mathrm{H}$ NMR

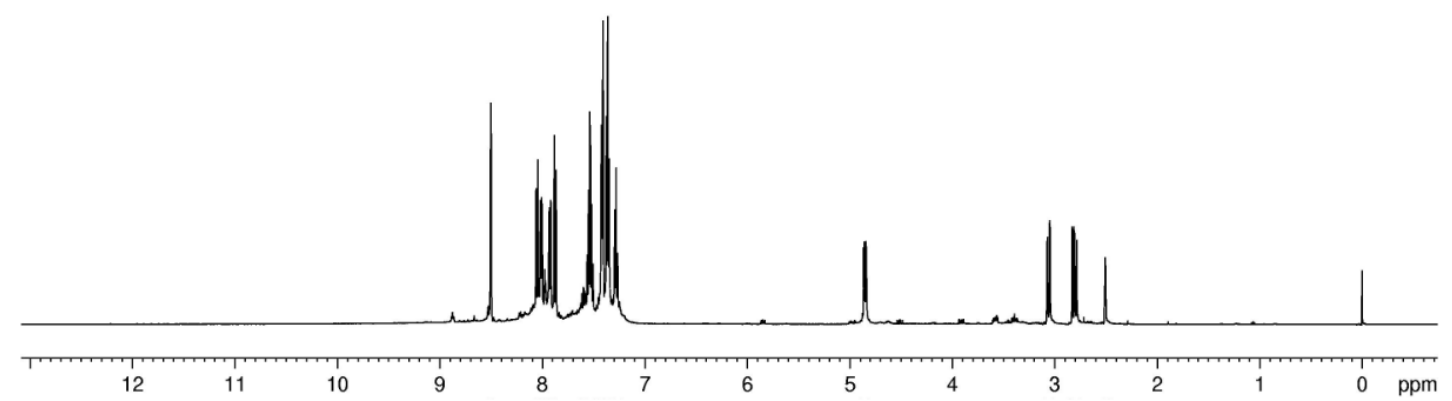

${ }^{13} \mathrm{C}$ NMR

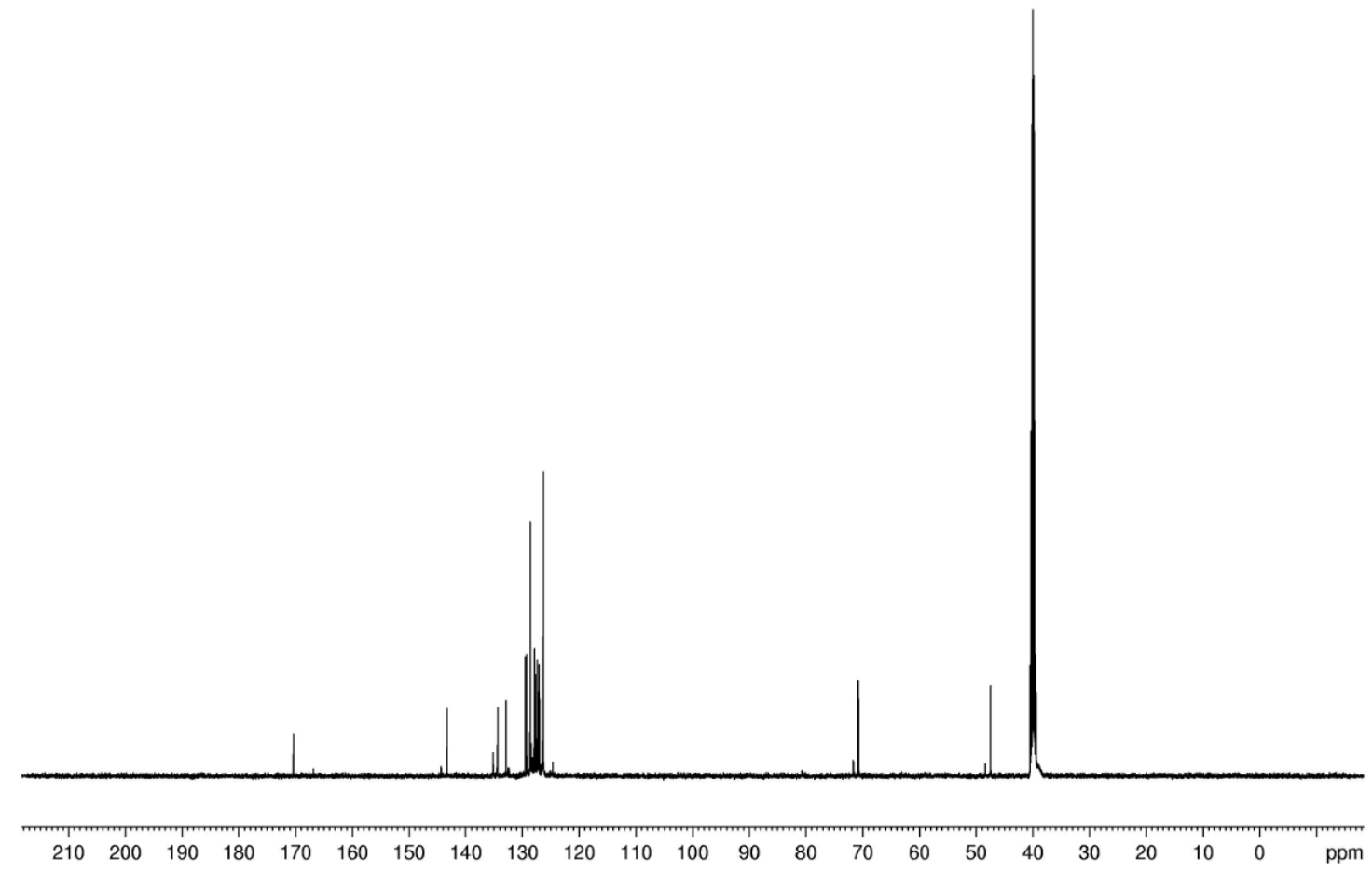




\section{Ila}

${ }^{1} \mathrm{H}$ NMR

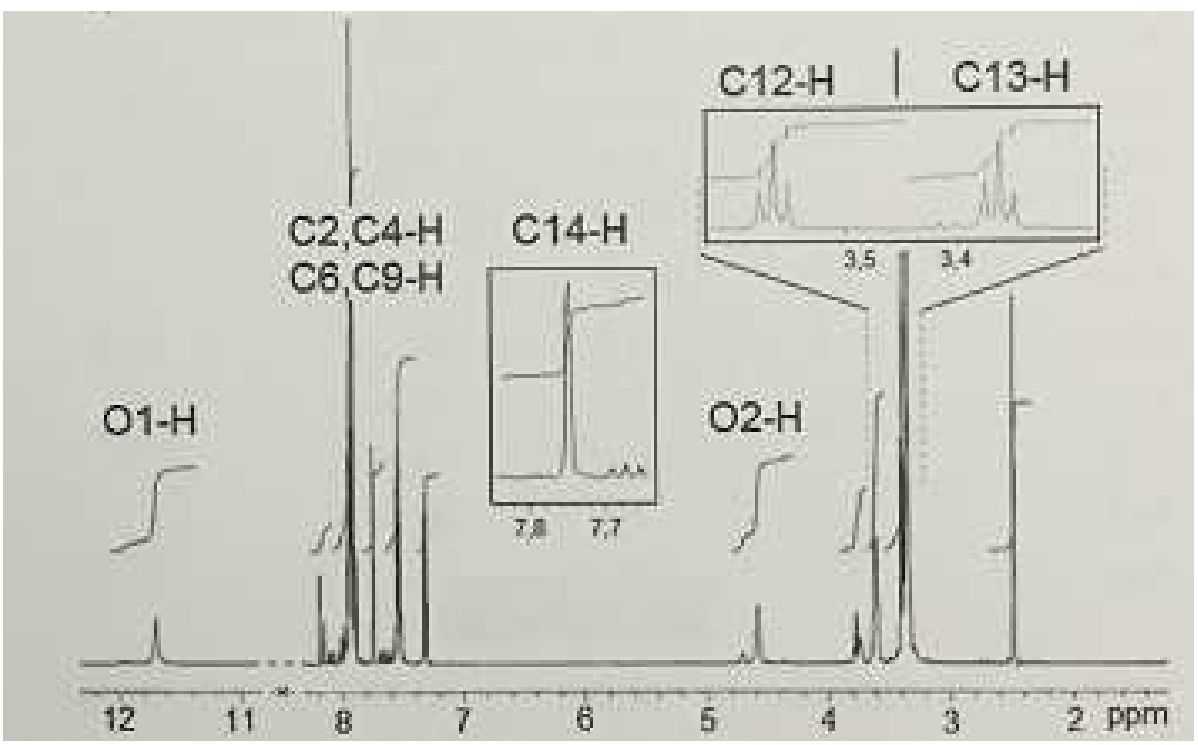

${ }^{13}$ C NMR

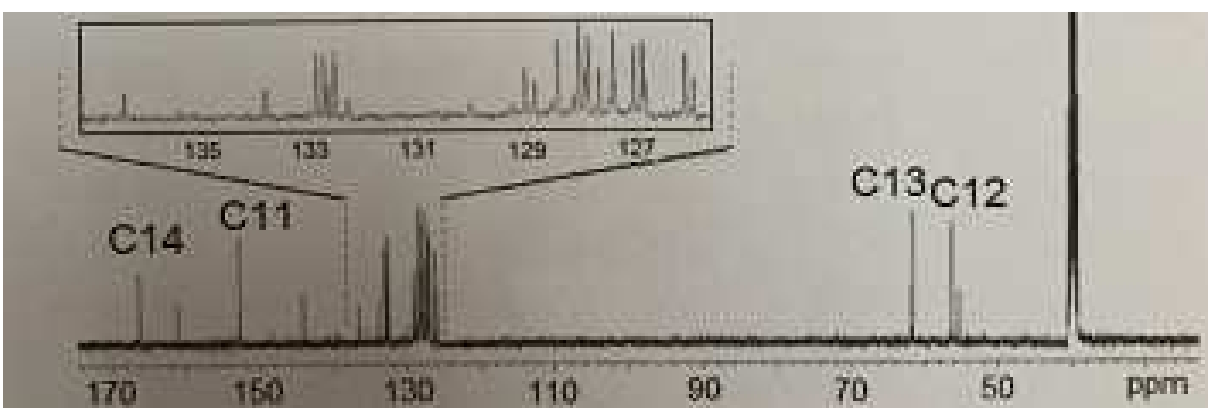


IIIb

${ }^{1} \mathrm{H}$ NMR

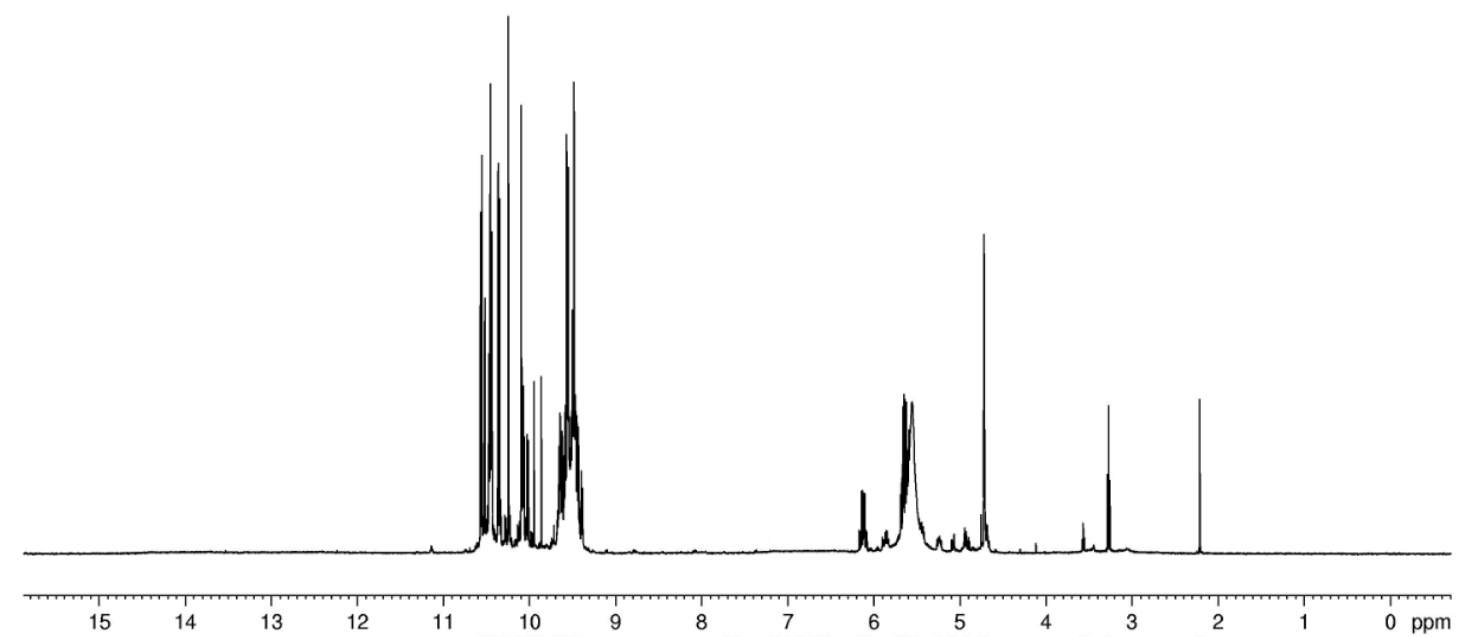

${ }^{13}$ C NMR

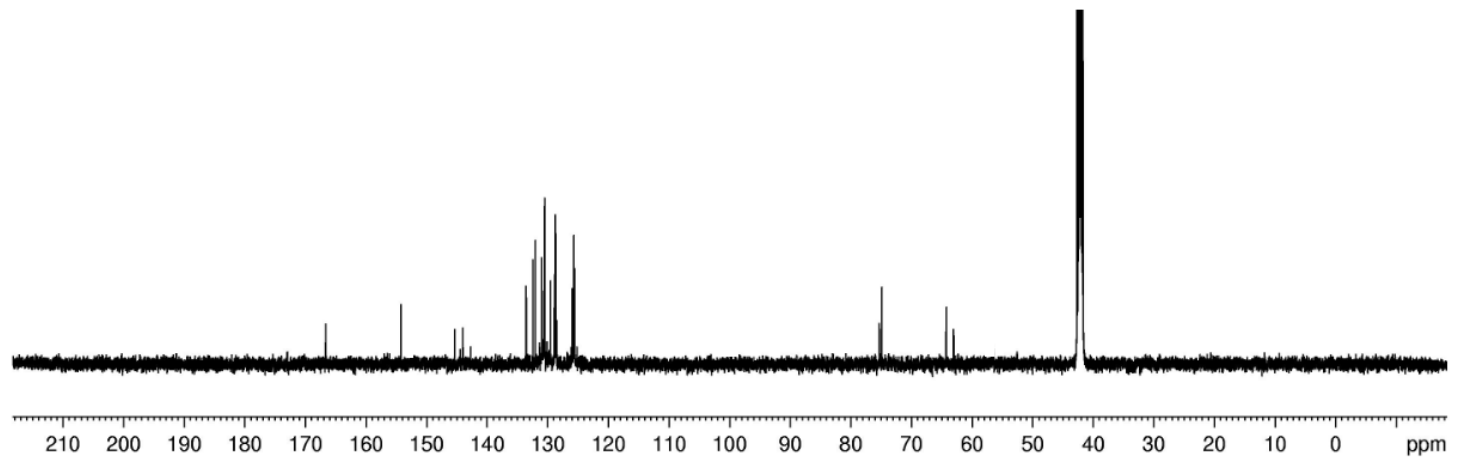


IVb

${ }^{1} \mathrm{H}$ NMR

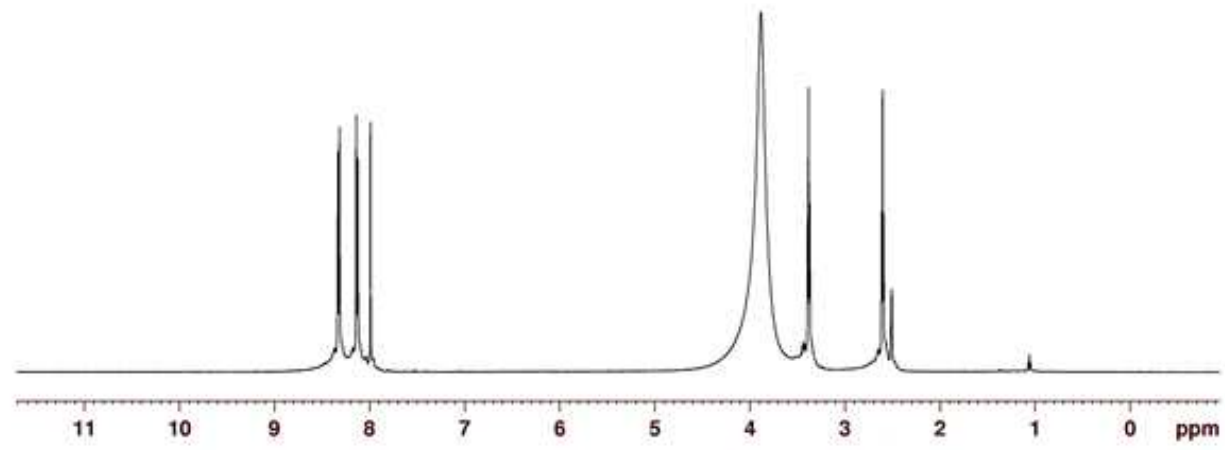

${ }^{13}$ C NMR

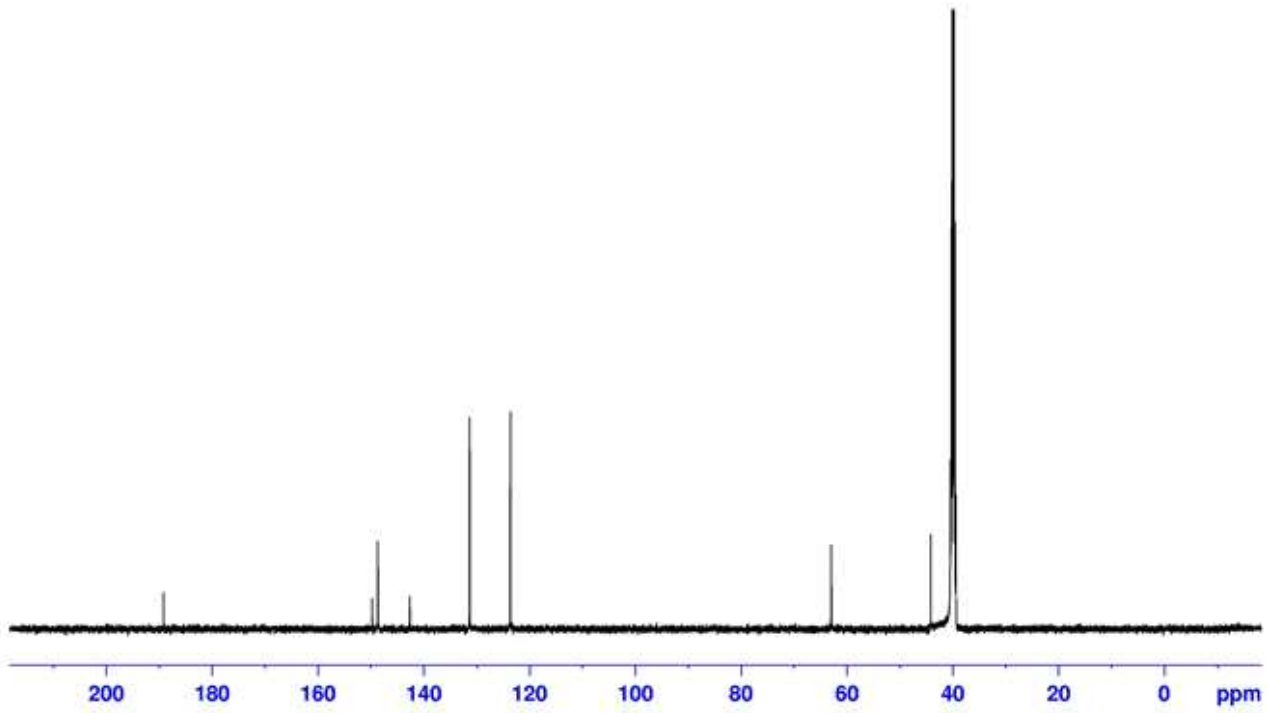


Figure S4. Theoretical NMR spectra
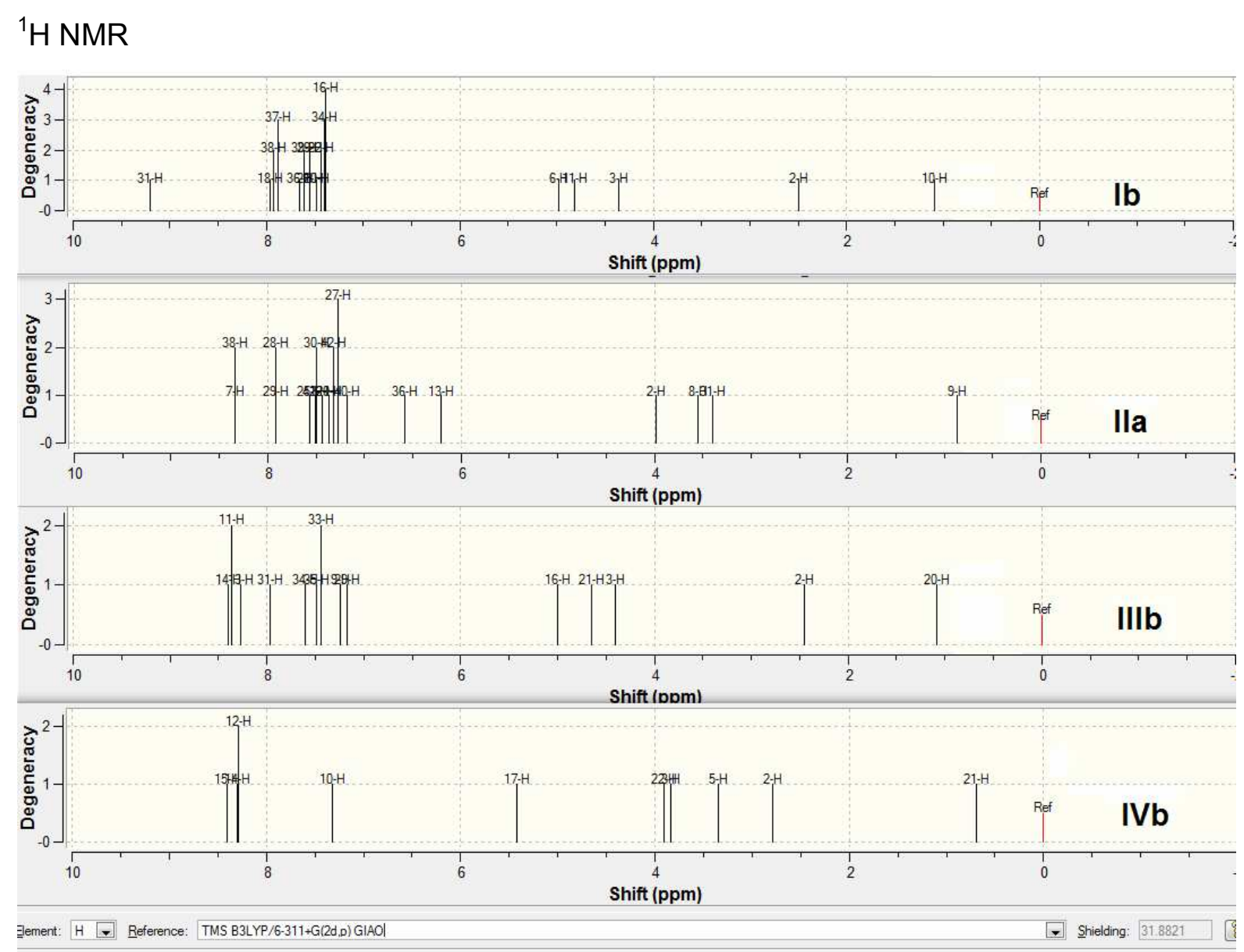


\section{${ }^{13} \mathrm{C}$ NMR}
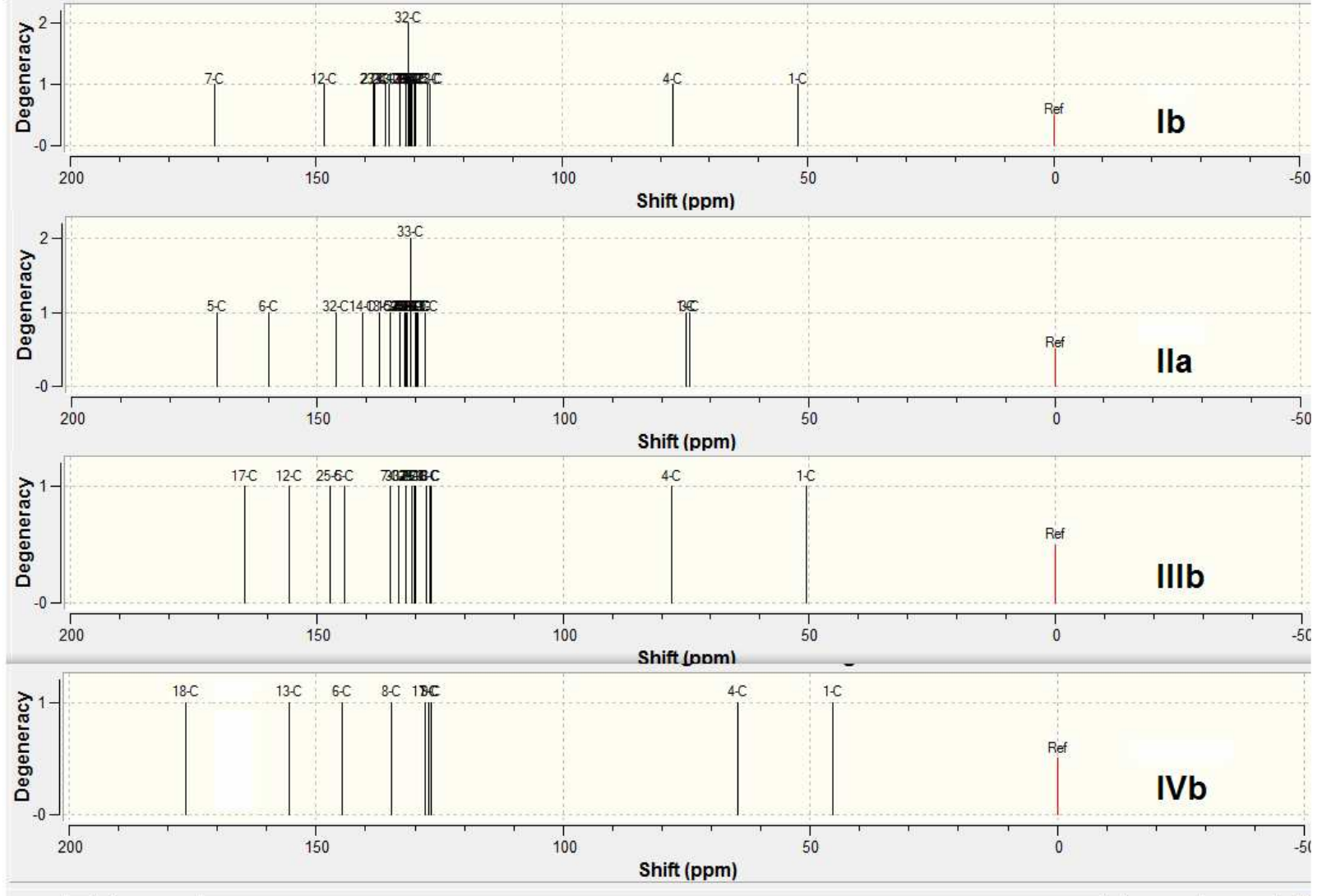

Element: $C$ Reference: TMS B3LYP/6-311+G(2d,D)GIAO 
Figure S5 The optimized geometries of the reactants, intermediates, transition states and products for the reaction of ninapH and pea.

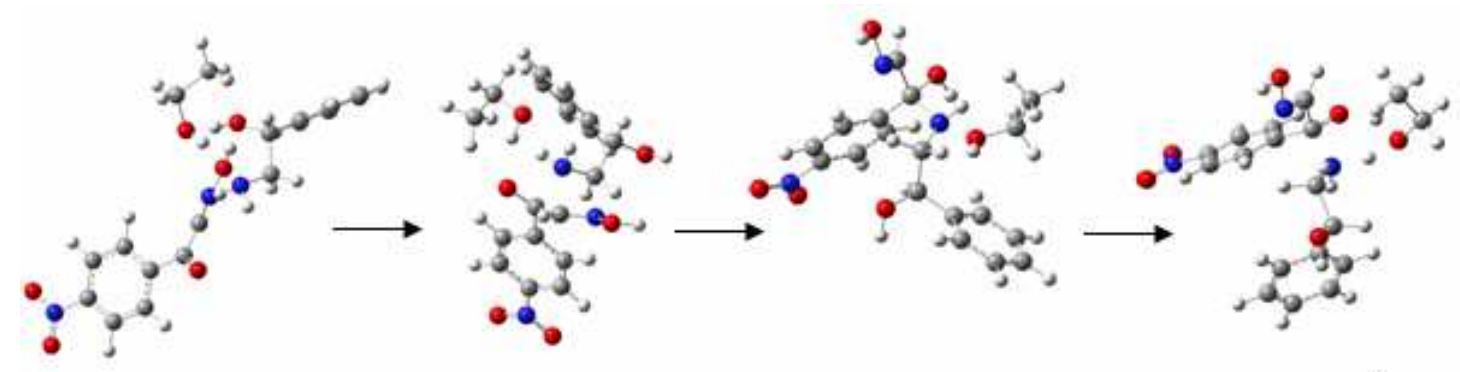

$$
\text { ninapH }+ \text { pea } \quad \text { TS1 IN1 }
$$
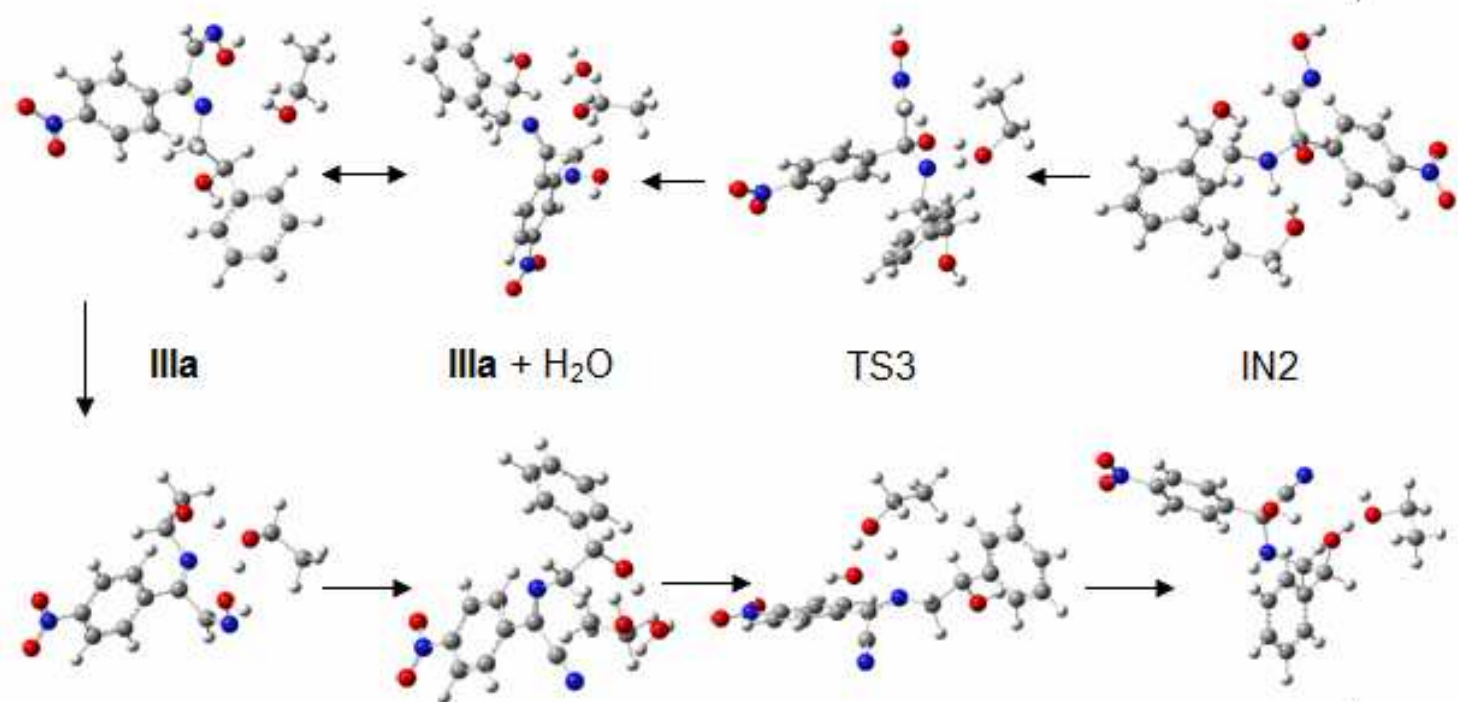

TS4

IN3

TS5
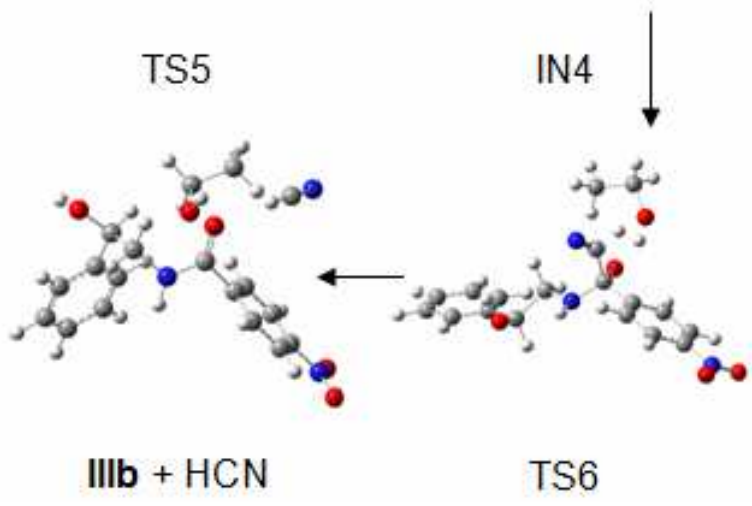
Figure S6 The optimized geometries of the reactants, intermediates, transition states and products for the reaction of ninapH and ea.
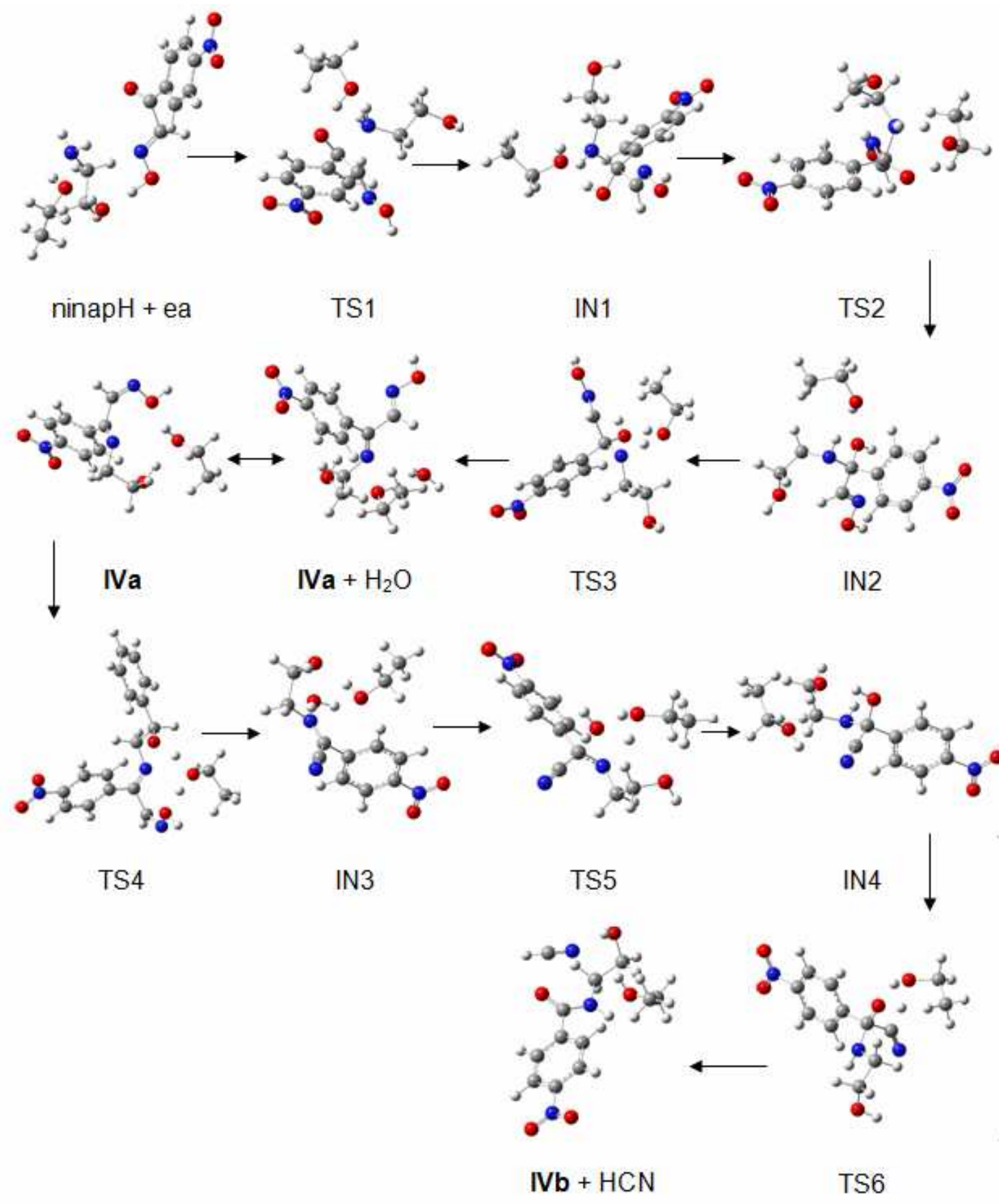